\title{
School case studies: Stories of self-evaluation
}

\author{
Jana Poláchová Vaštatková
}

Palacký University in Olomouc, Faculty of Education, Institute of Education and Social Studies

Received 23 July 2013; final version received 23 November 2013; accepted 2 January 2014

\begin{abstract}
The paper concentrates on self-evaluation as a strategy affecting the quality of education and supporting the development of schools from within. The paper presents the methodology of 30 case studies from Czech schools that demonstrate the course of school self-evaluation and its context. The analysis of study outputs/school stories allow to draw conclusions about the character of self-evaluation processes in terms of the change process. It shows that self-evaluation has gradually and slowly become a part of work of Czech schools. The conclusion draws the attention to the benefits of the selected research design for multi-case study methodology.
\end{abstract}

Keywords: self-evaluation, school, case study, change

The school self-evaluation can be approached from various perspectives: financial (as a relatively cheap mechanism ensuring high-quality school work), political (it is an incentive, however, it also represents a political regulation), participative (it allows a number of people to participate in the school activities, though at the same time it may exclude some of them at a particular moment), developmental (recurrent process of change management; professional development of individuals) (Kyriakides \& Campbell, 2004; Lakerveld \& Caals, 2006, and others). In pedagogical-psychological perspective, self-evaluation is interconnected with the learning process of pupils, teachers and other actors of school life (Nevo, 1994; MacBeath et al., 2006, and others). It is one of the strategies supporting the development of existing schools, especially in decentralized school systems in which the concept of accountability is reinforced.

Nevertheless, self-evaluation is not a common tool in all European school systems even though it has become quite a well-known phenomenon in recent years (see McNamara \& O'Hara, 2008). Its implementation depends on various factors such as educational system culture and its supervision methods (Meuret \& Morlaix, 2003), the expected school accountability, the 
level of external support for schools (i.e. providing teachers with education and consulting), but mainly the attitude of relevant schools, their teachers and other actors of the school life. The growing number of examples from Czech schools (see Vaštatková, 2005; MacBeath et al., 2006; Syslová, 2010 and others) proves that in some schools it is indeed a process initiated by the actors of the school life. They obtain stimuli for their subsequent work and for higher quality of the whole school through their systematic, systembased and cyclical work with effective feedback (see Vanhoof \& Petegem, 2007). This, however, does not apply to a large number of Czech schools as self-evaluation in many of them still remains a challenging part of their work (see e.g. conclusions of the Czech School Inspectorate; Vaštatková, 2010 and others). Based on the analysis of 30 multi-case school studies, this paper aims to determine the nature of Czech school self-evaluation with respect to the change implementation and management. In the conclusion, the contribution of selected research design is considered from a methodological point of view.

\section{The possibilities of researching the school self- evaluation: School case study}

Self-evaluation is a relatively new process for Czech schools, which is why one of the significant questions for education policy makers is how to promote its meaningful implementation in schools. There are more possible strategies for reaching this goal, e.g. saturation of explicitly expressed educational needs during further education process, providing a battery of valid and reliable evaluation tools etc. These initiatives, however, may face various difficulties such as limited understanding of self-evaluation as the implementation of several steps rather than a longterm and comprehensive process that is to affect the functioning of the whole school. Untrue or insignificant information may be obtained which is "the worst scenario that can happen during self-evaluation" according to MacBeath (1995). Teachers and headteachers may also fail to realize that self-evaluation is a specific process of change management that needs to be regarded as a natural part of contemporary pedagogical profession. In addition to procedural-developmental and professional-administrative dimension, school self-evaluation also has other dimensions: social-cultural, communication-collective and relational-contextual (Vašt́atková, 2010). The last three dimensions explain that self-evaluation processes can be carried 
out in specific schools only, among a specific kind of people, their habits, expectations that are explicitly expressed as well as implicitly perceived; other important factors are the culture in that particular organization and in its neighborhood (region, community and region). In order to prevent the self-evaluation from being perceived only as formal fulfillment of external requirements laid upon school, it is important that people at school want to implement it and consider it as a natural and necessary step in time that helps them develop their skills and subsequently improve themselves in evaluation activities (thus shifting from a single loop to triple loop learning). Is it possible to encourage meaningful implementation in many schools? This question was also raised by the Road to Quality Improvement project ${ }^{1}$ which made an effort to support willingness and provide inspiration. It aimed to create a categorized electronic database of quality management cases, i.e. to gain and to share examples of good practice since one of the most efficient methods in terms of adult teaching is the learning from experience. And if a certain organization, teaching staff or an individual have no experience of meaningful self-evaluation processes, there is a possibility to convey the experience of others through written stories, "best practice", "good practice" cases (see Veselý, 2010) etc. Following chapters summarize the information obtained from the project activity implementation during which thirty school case studies were conducted and their conclusions were presented in Chvál et al. (2012) and Poláchová Vaštatková et al. (2012).

\subsection{Methodology of case studies}

Good practice research is a specific kind of case studies (Veselý, 2010). Individual studies were conducted subsequently in the course of three years. Their methodological framework was represented by holistic-descriptive case studies (for more details see Walterová, 2002) as the researchers were searching for answers as to why and how self-evaluation proceeds in a certain context; they were trying to detect the evolvement of ways and principles of its implementation, presentation of its subsequent findings as well as further work with those findings (which corresponds to the concept of intrinsic case studies according to Stake, 1995). Each case was conducted

Full title of the project: SELF-EVALUATION - Creation of the system and support for schools in the self-evaluation field (CZ.1.07/4.1.00/06.0014; 2009-2012). It was aimed at supporting schools in a versatile way in the field of self-assessment in a decentralized system of education. 
during approximately 18 months of cooperation among the researcher, teachers and headteachers from the respective school, the author of the text and other experts educators, in particular reviewers of relevant texts. This allowed deeper understanding and approaching the observed phenomenon in a specific context. The team represented by many authors, a wide range of school stories written in the "language of common teachers" ${ }^{2}$ and published on the project website (using hyper-links that mostly refer to the original school documents) ${ }^{3}$ indicate high specificity of these case studies in the Czech environment.

The criterion for a case selection was the stable school management (e.g. a headteacher being in the position for several years) and at the same time at least two people (a researcher, an inspectorate member, a chairman of a certain school association, a school consultant, a member of teaching staff...) described the school as "good practice with processes obtaining feedback within quality management". It was also necessary to get the informed consent from the management of the selected school. ${ }^{4}$ One of the basic requirements for the case selection was the variety of the respective schools. Selected cases were collected from all regions of the Czech Republic (as education authorities and regions can affect the form of external evaluation that may subsequently influence the character of self-evaluation). The cases included different types of schools: from few-class schools to schools merging three originally separate schools; village and city schools; schools with different ways of implementing the self-evaluation, from informal processes to formalized ones (e.g. by ISO standards); the selected cases included schools observing the relevant framework education programme for several years as well as those for which it was created only a short time ago. As far as the education authority was concerned, these schools were established by regions and municipalities, there was one church school and two private

2 "Quotations of statements of the participants in the self-evaluation process are priceless for a dedicated school headeacher or teacher; they can get a picture of the level of details and school evaluation, of how far this process can be taken and what risks there are." (says one of the reviewers)

3 "Supplementing one's own reports with attachments offers a chance to view the selfevaluation process in this school as a whole. The school headteacher or a school employee authorized to carry out the evaluation for his/her section can use the examples presented in the attachments in his/her practice..." (says one of the reviewers)

4 The instructed approval also included a decision from the school referring to the extent of maintaining anonymity when publishing reports (e.g. one elementary school of art required utter anonymity). 
schools - established by corporate bodies. Sequential way of carrying out the studies allowed gradual selection of schools and researchers.

Researchers conducting case studies are generally considered the main source as well as the limit of the quality of the study (see e.g. Miovský, 2006). The specificity of the studies described in this text consists in the variety of the professional background of the authors' team. All authors can be regarded as experts on self-evaluation processes, however, their expertise is of different kinds. The team included representatives of qualified school management practice, representatives of profession-related associations (Czech Society for Quality), consultants in school development, representatives of organizations providing further education for teachers, experts from academia employed by four different universities in the Czech Republic and representatives of teachers, participating in the school self-evaluation. The selection strategy was based on positive references, willingness and expertise of the researchers as well as their time flexibility and physical ${ }^{5}$ possibility to participate in conducting the study. 24 experts conducted the studies (closely cooperating with approx. 90 teachers and other participants from respective schools) who were supervised by the author of the text. Reviewers of the reports also contributed to those studies significantly, they commented on the studies of the same type as the one they were employed at.

At the beginning of the study development there was a plan called Conducting Strategy. It was based on theoretical-conceptual framework that contained study objectives, a battery of questions revising study contents. The plan characterized the main methods and principles to ensure the quality (see Maxwell, 2005, p. 5 in Dvořák et al., 2010, p. 45) called Quality Standards. Quality Standards also included Ethical Principles that subsequently adjusted the process of study conduction ${ }^{6}$ and the submission of running and final reports. Reports from these studies are written as school stories (see Vaštatková, 2007; Veselý, 2010) because this form allows readers to perceive the causes and connections between events and phenomena better.

5 The term physical means to physically enter the schools, to interview the participants etc., which required a relative geographic vicinity to the location of the researcher and the described school, or the options for easy transportation. This "physical" requirement was once also a reason for the rejection of an already selected school since it was impossible to find the study guarantor within acceptable distance.

6 One of the most challenging moments during studies conduction turned out to be when the researchers inclined to act as consultants as a result of their coexistence with the school, but they had to remain independent observers and record-keepers. 
"Every school has its own atmosphere, its particularities and every orchestra prefers different tunes..." (says one of the reviewers). A different context of school work adds a specific framework to its story (see Merriam, 1998). The standards of the formal layout of the stories were developed for the authors as well. The objective was to ensure for all the stories to have the same structure and to be transparent to the readers. The electronic version of the stories together with hypertexts allowed the readers to study authentic school documents, tools developed at schools etc. Part of the strategy for guiding authors during conducting the studies, from a simple description of individual activities to depicting the self-evaluation process in the context of the whole school, was to continuously provide feedback, i.e. mutual response from different perspectives and in a different way (especially from the test author, but also with the utilization of a web-interface, personal contacts etc.). In order to ensure the validity, a member verification was applied, consisting in submitting the running and final reports to the management of the described schools (see Švaříček \& Šed'ová et al., 2007, p. 33). The review of the final text of the story carried out by an independent reviewer/expert ${ }^{7}$ was also a tool for ensuring external validity (Veselý, 2010).

\section{Character of self-evaluation in Czech schools}

The implementation of self-evaluation may represent a change in some schools but it can also be considered a tool for implementing and managing change. Changing the school work is not a single event. It is a process that continues in mutually interlinked phases. Most authors mention three main phases and highlight also various factors that determine this whole process. The phases are described e.g. by Lagerweij (1995) as initiation, implementation and incorporation. This model is used during the analysis of created stories.

In the first or initial phase the basic (and not certain) thing that matters is the issue that needs to be well received and understood by those who have to implement it. Lagerweij (1995) as well as other authors (cf. e.g. Fullan, 2005; Lieberman, 2005) highlight the crucial importance of certain circumstances for understanding and acceptance of the change. It is all about the relationship between the change and the existing needs of the school, the clarity and

7 Reviewers were selected from headteachers of the similar type of schools and specialization so that they have rich experience of self-evaluation. 
nature of the content of the proposed change, the stimulation of the external environment, the availability of necessary resources, how and whether the change is relatively convenient for the participating, the compatibility of the change with existing opinions and beliefs, the complexity of change, whether it is possible to verify the change and whether there are observable results of efforts for change in particular. The school stories demonstrate that even in this specific group, not all schools were convinced of the need for a change in the form of self-evaluation process at the very beginning of their "autonomy" And that a lot of time is required but also multilateral support and stimulation from the management of the school and the external environment is highly needed. This can be proved by the following quotations from the stories.

The school headteacher aimed to create a high-quality management system that would allow an efficient communication among all operations. (deputy head of kindergarten and elementary school)

The first real step in the self-evaluation and the first useful self-evaluation tool was the obligatory self-evaluation of the school headteacher in 1997 (the obligation was imposed by the education authority). (headteacher of an art school)

The implementation phase is currently typical for two-thirds of schools surveyed. But even though the partial success is recorded, the change itself is not an everyday part of school life. An important factor is the content of innovation, the type and individual character of the school and its social environment (external support...) (Largeweij, 1995). On the basis of school self-evaluation, different issues are being changed: reflective practice is being developed, the opportunities for participation of various groups are being provided, suggestions for further work are being identified.

Of course, at first it was a duty. But later, when one becomes familiar with the situation, it shows some strong and weak points. One can see what has been done, what should be done and where it headed. Now we are going to find out what e.g. pupils or teachers would like. One has never dealt with something like this before... (from the contents of a grammar school story)

8 In current conditions, Czech schools have considerable autonomy. As of 1 January 2003, all of them became legal entities. From 1.1. 2005 to 1. 9. 2012, depending on the pace of the development of framework education programmes, they received relative pedagogical autonomy, they gradually turned to teaching based on their own school education programmes. 
It has provided us with a comprehensive system of all internal regulations. However, there are some gaps when it comes to observing the new ones. (the extract from another school story)

As for the set-up of the evaluation team and the involvement of the representatives of different actors of the school life, the school management played the main role in all cases; teachers were participating with different intensity. Parents and pupils act as respondents, those who give feedback and those to whom the findings are presented. There are many findings related to practical aspects of the self-evaluation process (such as deadlines, target groups, areas, objectives, partial and full responsibilities...), however, they are so varied that it is difficult to classify them. Nonetheless, the increasing tendency towards electronic evaluation tools as well as creation and utilization of one's own tools can be determined.

At first various questionnaires were conducted and evaluated by the school headteacher and his deputy manually. When wewere processing the questionnaires with the headteacher for the first time, one of us took it and the other one counted the results. Subsequently the school management decided to delegate authority more efficiently and for online collection/processing of the data in this specific area of education evaluation... (from the statement of the management of one of described schools)

An accompanying evaluation method utilized by our school during the described evaluation period for all events which were organized were video recordings. They were a sort of participant observation when school events had been recorded to be discussed and evaluated later. The behaviour of the participants was described and evaluated; the way the children, their parents and the public got involved in the activities, whether their facial expressions show satisfaction, enthusiasm, ..., whether the event was attended by most parents and siblings of the pupils... (from an elementary school story)

Some schools rely fully or partially on external impulses (non-commercial and commercial companies and activities, involvement of external managers of quality, informal external help from other colleagues...), others implement self-evaluation procedures independently and they "only" rely on conclusions from inspection reports and from formal and informal benchmarking.

We are not stuck in one place. First we had self-evaluation made to order based on the Kilmann-Saxton Culture Gap questionnaire (in 2005/2006 and 2006/2007). Its results, positive and negative, forced us to investigate certain areas in more 
detail; we wanted to improve some things and to find out whether and how successful we were. Therefore we decided to work on self-evaluation by ourselves in the next period... For self-evaluation needs the school utilizes its own evaluation tools... In 2009, when there was a second self-evaluation of our school, the school used a questionnaire inquiry that could be compared with the previous period. (headteacher of primary school)

Regarding the adopted measures based on the implemented self-evaluation, there is only little information on it in the stories of the thirty schools. The stories mostly just mention necessary changes which have been embedded into school development plans. This is logical as the adopted measures refer to the TABOO issues. Their revelation in the highly competitive environment of Czech schools would show detected flaws, i.e. confidential school data, which could turn against all schools. The stories describe efforts to implement metaevaluation activities, too. This involves reflection of the past self-evaluation cycles, which relates to a gradual beginning of the incorporation phase of the self-evaluation process into school work.

What are the benefits of self-evaluation for the school? A number of interesting findings and the motivation to improve or to focus on challenging aspects in the first place. Since we are beginners in the area of self-evaluation, we have proceeded through the trial-and-error method. For example, we have developed evaluation tests but we keep modifying their contents. It is very difficult to develop the tests; the main question is what information pupils should be provided with, which subject area outputs are the most important... (headteacher of one of the described schools)

The third, incorporation phase of the change implementation and management supports and strengthens new working behaviour resulting in incorporating the necessary changes. The incorporation phase is rarely represented in the group of researched schools, though. From a certain point of view it is logical because it is a long-term phase. For changes whose complexity is comparable to that of the self-evaluation, the horizon of two to five years is estimated if it is to become an everyday part of the "organization body".

The headteacher of a professional school confirms:

To carefully explain to the teachers that the work they are doing has its qualities, but also that it could be done differently is admirable art. However, to further expand someone's horizon, to convince them that it is useful to think about things 
in a different way from how they used to, and to stimulate them effectively, is mastery. It's a long haul, where results cannot be expected in the first few years, there might even be none ever.

Among the factors affecting the quality and performance of incorporation phase, there is mainly the support of education policy, the main theme which includes external aid, but also the existence and availability of internal help, especially from the school management. It is equally important to "get things" to the level of the class (it should start there ideally), i.e. as close to the key processes of school work - learning and teaching.

The text of an elementary school story reveals:

Every year the results of pupils' school work are evaluated in specific forms processed by the deputy head. These involve the results of mid-year and end-year marking, the results of quarterly laboratory work, the results from competitions, Olympiads etc. In order to evaluate the results of pupils' education, there is gradual "standardization" of educational and evaluation processes at school. We discover e.g. the methodology of preparation, writing and evaluation of quarterly work, laboratory work, timetable of the implementation of these activities during an academic year, the methodology for preparation of background documentation for a homeroom teacher at the pedagogical board. The objective is to integrate and to make all activities transparent for teachers as well as to ensure their comprehensibility for pupils and parents, which allows the comparison of the performance of pupils and teachers and facilitates the supervision by school management... Standardization? It is also pleasant, it simplifies things.

\section{Conclusion}

The completed studies have shown that self-evaluation can indeed be a good strategy for promoting meaningful use of relative autonomy in which schools act proactively within the changing organization caring about the quality of work in close contact with the immediate surroundings. But this happens neither immediately nor automatically. In many Czech schools it has not yet been incorporated. The main reason is that in the initial stage, not all participants understood the content of the change/school self-evaluation, they were not aware of the benefits of its implementation. Everything has been discovered gradually, even intuitively. In addition, for quite a long time teachers were not supported in their efforts systematically and systemically by the external environment. The stories proved that the roads to quality are 
unique, paved with success as well as difficulties, dead ends and hesitation. That the sense of meaningfulness of these processes grows gradually and that everything is determined by support from the school headteachers. In many cases the value of self-evaluation was confirmed by the most important aspect of school life: with increasing quality of educational school work.

As observed by one of the reviewers:

Everything we do in self-evaluation should always be reflected in a higher-quality curriculum. The story is valuable because it demonstrates how to turn selfevaluation into an active tool for the development of school and all participants in the educational process, how to avoid formalism and what educational benefits can be obtained.

The multi-case school studies have captured the mechanisms that utilize the latent opportunity to create certain value: "essential" and "supportive" (Bardach, 2000, p. 77), i.e. they have given an idea of which aspects of school life are necessary for the concept of self-evaluation as an integral part of high-quality school work. This supported deeper understanding of detailed characteristics of self-evaluation processes in Czech environment beyond the framework of the examined schools. Findings also often extend the knowledge related to the operation of certain types of schools (for example, until now the research has not paid attention to elementary schools of art, conservatoires, vocational schools). A battery of outputs that can be used as an educational tool for various participants has been provided. It is useful for teachers, pupils, school managers as well as education authorities. From the methodological perspective the benefit of the case studies can be seen in the extended research strategy of the case study, specifically with the aspects of multi-case characteristics. Individual cases had unified design, which offered certain elementary possibilities for generalization of the obtained information about the character of self-evaluation in Czech schools.

\section{References}

Bardach, E. (2000). A practical guide for policy analysis. The eightfold to more effective problem solving. New York: Chatham House Publishers.

Dvořák, D., Chvál, M., Starý, K., Urbánek, P., \& Walterová, E. (2010). Česká základní škola. Vícepř́padová studie. Praha: Karolinum.

Chvál, M., et al. (2012). Školy na cestě ke kvalitě. Systém podpory autoevaluace škol v ČR. Praha: Národní ústav pro vzdělávání. 
Kyriakides, L., \& Campbell, R. J. (2004). School self-evaluation and school improvement. A critique of values and procedures. Studies in Educational Evaluation, 30(1), 23-36.

Largeweij, N. (1995). Izmenenije obrazovanija čerez razvitije školy. In P. Karstanje \& P. Ušakov (Eds.), Upravlenije v obrazovanii: problemy i podchody (pp. 15-37). Moscow: Sentjabr.

Lakerveld, J. V., \& Caals, A. (2006). Self-evaluation in life long adult learning. Grundtvig. Retrieved from http://www.sealll.eu/docs/SealllframetextJaapAnita.pdf

Meuret, D., \& Morlaix, S. (2003). Condition of success of school's self-evaluation: Some lessons of a European experience. School Effectiveness and School Improvement, 14(1), 53-71.

MacBeath, J. (1995, February). Reflections on school self-evaluation. Plenary speech presented at School self-evaluation conference, Athens.

MacBeath, J., et al. (2006). Serena aneb Autoevaluace škol v Evropě. Ždár nad Sázavou: Fakta.

McNamara, G., \& O'Hara, J. (2008). The importance of the concept of self-evaluation in the changing landscape of education policy. Studies in Educational Evaluation, 34(1), 173-179.

Merriam, S. B. (1998). Qualitative research and case study applications in education. San Francisco: Jossey-Bass.

Miovský, M. (2006). Kvalitativní přístup a metody v psychologickém výzkumu. Praha: Grada.

Nevo, D. (1994). Combining external and internal evaluation. A case for school-based evaluation. Studies in Educational Evaluation, 20(1), 87-98.

Poláchová Vašţatková, J., et al. (2012). Autoevaluace v praxi českých škol. Praha: Národní ústav pro vzdělávání.

Stake, R. E. (1995). The art of case study research. Thousand Oaks: Sage.

Syslová, Z. (2010). Průběh vzdělávání jako jedna z oblastí vlastního hodnocení mateřské školy. Praha: PedF UK.

Švaříček, R., \& Šed'ová, K., et al. (2007). Kvalitativní výzkum v pedagogických vědách. Praha: Portál.

Veselý, A. (2010). Teoretické a metodologické základy „výzkumu“ dobré praxe. Aula, 18(3), 3-17.

Vaštatková, J. (2010). Autoevaluace a benchmarking ve škole. Olomouc: Hanex.

Vaštatková, J. (2007, April). K realizaci autoevaluace $v$ českém prostredí. Plenary speech at the SKAV conference Uděláme z vlastního hodnocení nástroj pro řízení a rozvoj školy?, Praha.

Vaštatková, J. (2005). Autoevaluace jako nástroj změny české základní školy. Olomouc: PdF UP v Olomouci.

Vanhoof, J., \& Petegem, V. P. (2007). Matching internal and external evaluation in an era of accountability and school development: Lessons from a Flemish perspective. Studies in Educational Evaluation, 33(2), 101-119.

Walterová, E. (2002). Fungování základní školy: pilotní případová studie. In Rozvoj národní vzdělanosti a vzdělávání učitelů v evropském kontextu. II. (pp. 9-23). Praha: PdF UK.

\section{Author}

Jana Poláchová Vaštatková, Palacký University in Olomouc, Faculty of Education, Institute of Education and Social Studies, Žižkovo nám. 5, 77140 Olomouc, e-mail: jana.polachova@upol.cz 


\section{Př́padové studie škol: příběhy autoevaluace škol}

Abstrakt: Příspěvek je věnován autoevaluaci jako strategii ovlivňující kvalitu vzdělávání a podporující rozvoj škol zevnitř. Představuje metodologii vzniku 30 případových studií českých škol, které zachycují průběh i souvislosti autoevaluace. Analýza výstupů studií psaných ve formě příběhů škol pak umožňuje stanovit závěry o charakteru autoevaluačních procesů z hlediska zavádění změny. Ukazuje, že se autoevaluace pozvolna a postupně dostává do života českých škol. V centru zájmu je i posouzení přínosu zvoleného výzkumného designu pro metodologii vícepř́ípadových studií.

Klíčová slova: autoevaluace, škola, případová studie, změna 